\title{
PemanfaAtan Sumber Daya Alternatif Untuk Kemandirian Pangan Di KelURAHAN GUNUNG TANDALA TASIKMALAYA
}

\section{${ }^{1}$ Adhitya Rahmat Taufiq, ${ }^{2}$ Deden Mulyana, ${ }^{3}$ Mohammad Soleh Soeaidy, ${ }^{4}$ Allicia Deana Santosa}

\author{
1,2,3,4 Manajemen, Fakultas Ekonomi, Universitas Siliwangi, Jawa Barat, Indonesia \\ email: ' adhityarahmattaufiq@unsil.ac.id, ${ }^{2}$ dedenmulyana@unsil.ac.id, \\ ${ }^{3}$ m.solehsoeaidy@unsil.ac.id, ${ }^{4}$ allicia@unsil.ac.id
}

\begin{abstract}
The implementation of restrictions on social interaction, due to Covid-19, has caused many business sectors to experience difficulties and lay off their employees. The Indonesian Employers' Association (Apindo) noted that the number of workers who were laid off and laid off during the Covid-19 pandemic has so far reached 7 million people, this has a big impact because many people have lost their income in the midst of the food security crisis, especially for workers. Tasikmalaya City embroidery industry. The purpose of this community service program is to provide knowledge and training regarding the use of alternative resources to maintain food independence for people who have lost their jobs in the embroidery industry in Tasikmalaya City. Alternative activities given are simple urban farming and catfish cultivation in buckets. The training methods provided include providing basic knowledge and examples regarding the implementation of simple urban farming and catfish cultivation in buckets. This activity succeeded in increasing their literacy regarding the stability of food independence and understanding the potential market opportunities of this activity.
\end{abstract}

Keywords: alternative resources, urban farming, food self-sufficiency

\begin{abstract}
Abstrak. Pemberlakuan pembatasan interaksi sosial akibat Covid-19 menyebabkan banyak sektor usaha mengalami kesulitan dan merumahkan karyawannya. Asosiasi Pengusaha Indonesia (Apindo) mencatat jumlah pekerja yang terkena pemutusan hubungan kerja $(P H K)$ dan dirumahkan di tengah pandemi Covid-19 sejauh ini mencapai 7 juta orang. Hal ini berdampak besar, banyak orang kehilangan pendapatan di tengah krisis ketahanan pangan, khususnya untuk pekerja industri bordir Kota Tasikmalaya. Tujuan dari program pengabdian kepada masyarakat ini adalah memberikan pengetahuan dan pelatihan mengenai pemanfaatan sumber daya alternatif untuk menjaga kemandirian pangan pada masyarakat yang kehilangan pekerjaan di industri bordir Kota Tasikmalaya. Alternatif kegiatan yang diberikan simple urban farming dan budidaya lele dalam ember. Metode pelatihan yang diberikan mencakup pemberian pengetahuan dasar dan contoh mengenai pelaksanaan simple urban farming, serta budidaya lele dalam ember. Kegiatan ini berhasil meningkatkan literasi mereka mengenai stabilitas kemandirian pangan dan memahami peluang pasar potensial.
\end{abstract}

Kata Kunci: sumber daya alternatif, urban farming, kemandirian pangan

\section{Pendahuluan}

Tahun 2020 merupakan tahun yang cukup berat bagi seluruh masyarakat dunia termasuk Indonesia. Hal ini dikarenakan munculnya jenis virus baru yang ditemukan pertama kali di Kota Wuhan, China, kemudian diberi nama Covid-19. Covid-19 atau Coronavirus Disease 2019 adalah penyakit baru yang menyebabkan gangguan pernapasan dan radang paru. 
Menurut BBC News, Covid-19 sudah mewabah dan menyebar dilebih 200 negara dunia, salah satunya Indonesia. Kasus Covid-19 di Indonesia per 17 Juni 2020 telah mencapai 41.431 kasus positif dengan jumlah korban meninggal mencapai 2.276 (corona.jakarta.go.id, 2020).

Penyebaran virus yang begitu masif dan cepat serta berakibat fatal terhadap tubuh manusia memaksa dunia melakukan banyak perubahan termasuk dalam melakukan kontak antar sesama manusia untuk menghindari penyebaran virus yang lebih luas. Pemerintah diseluruh dunia bertindak cepat dengan menerbitkan kebijakan membatasi masyarakat melakukan kontak antar manusia secara langsung. Pemerintah Indonesia memilih mengambil kebijakan PSBB atau Pembatasan Sosial Berskala Besar. Pembatasan tersebut meliputi peliburan sekolah dan tempat kerja, kegiatan keagamaan, kegiatan di tempat atau fasilitas umum, kegiatan sosial budaya, moda transportasi, dan kegiatan lain, khususnya terkait aspek pertahanan dan keamanan. Hal ini berpengaruh terhadap berbagai sektor, salah satunya banyak UMKM yang harus tutup. Banyaknya UMKM akhirnya harus gulung tikar di tengah situasi pandemi. Banyak pekerja dirumahkan, hal ini berpengaruh pada akses ekonomi masyarakat, yakni daya beli masyarakat menurun.

Asosiasi Pengusaha Indonesia (Apindo) mencatat jumlah pekerja yang terkena pemutusan hubungan kerja (PHK) dan dirumahkan di tengah pandemi Covid-19 sejauh ini mencapai 7 juta orang (Wardoyo, 2020). Salah satu UMKM yang banyak melakukan PHK adalah industri bordir terutama yang berada di wilayah Kecamatan Kawalu, Kota Tasikmalaya. Kecamatan Kawalu merupakan sentra industri bordir terbesar yang memberikan kontribusi positif bagi perkembangan industri di
Kota Tasikmalaya dan mampu menyerap lebih dari 10.000 tenaga kerja (data.tasikmalayakota.go.id, 2019). Sampai bulan April 2020 keputusan PHK atau merumahkan pekerja terpaksa dilakukan oleh industri bordir, yaitu sebanyak 1.569 pekerja dan terus mengalami penambahan sampai sekarang (Kompasiana, 2020). Hal ini menjadi masalah yang harus dipikirkan bersama, agar dapat solusi atau cara pekerja yang dirumahkan dapat bertahan hidup di tengah krisis pangan akibat pandemik ini.

Masalah ketahanan pangan merupakan masalah yang krusial pada situasi bencana, termasuk di saat wabah pandemik Covid-19 ini (Siche, 2020) yang masih belum berakhir dan semakin meluas di seluruh dunia ((OMS), 2020). Berdasarkan UU No 18/2012, ketahanan pangan merupakan kondisi terpenuhinya pangan suatu negara sampai dengan setiap individu masyarakat nya, dicerminkan melalui kondisi ketersedian pangan yang cukup, aman, beragam, bergizi, merata, dan terjangkau, serta tidak bertentangan dengan agama, keyakinan, dan budaya masyarakat. Food and Agriculture Organization (FAO, 2020a) menyatakan bahwa Covid-19 mempengaruhi dua hal signifikan, yaitu pasokan dan permintaan pangan. Kedua aspek ini, terkait langsung dengan ketahanan pangan, sehingga berisiko terjadi krisis ketahanan pangan. Menanggapi peringatan dari FAO, Presiden Jokowi telah memerintahkan jajarannya untuk terus mengontrol ketersediaan bahan pokok hingga ke daerah-daerah. Ketersediaan akses terhadap sumber makanan untuk dapat memenuhi kebutuhan dasar juga mengindikasikan ketahanan pangan (Rosales \& Mercado, 2020). Berbagai larangan dan peraturan yang membatasi kegiatan masyarakat di tengah kondisi pandemi Covid-19 ini mengakibatkan kesulitan dalam 
ketersediaan akses terhadap makanan, terlebih lagi dengan kondisi pandemik yang semakin memburuk. Jumlah penduduk yang mengalami kelaparan dan malnutrisi akan semakin meningkat di tengah terjadinya pandemi (Burgui, 2021)

Masyarakat Kota Tasikmalaya terutama yang berada di Kecamatan Kawalu memiliki peluang untuk membangun kedaulatan dan kemandirian pangan. Dalam masa pandemi seperti ini, masyarakat cenderung menjadi lebih kreatif. Termasuk halnya dalam menjaga akses terhadap pangan. Masyarakat dapat memanfaatkan sumber daya yang ada di lingkungan sekitar mereka untuk sumber pangan maupun melakukan inovasi agar dapat memiliki nilai jual, salah satu caranya adalah dengan urban farming ataupun berternak. Selain untuk kemandirian pangan dan konsumsi pribadi, kedua hal tersebut juga dapat membuka peluang usaha untuk masyarakat (Kullu et al., 2020) sehingga dapat meningkatkan perekonomian mereka sebagai solusi atas dampak PHK atau "dirumahkan" dari pekerjaannya. Sebagai contoh, dari aspek ketersediaan bahan pangan di konsumen, terjadi banyak perubahan pola karena kebijakan physical distancing. Situasi ini membuat pasar modern dan pasar yang berbasis daring menjadi jalur pasokan yang lebih banyak dipilih. Dari sisi transaksi yang dilakukan konsumen, pandemik membuat perubahan pola transaksi ke arah ke platform digital atau online. Menanam tanaman obat sangat bermanfaat untuk menjaga kesehatan di saat pandemik seperti ini, selain bermanfaat bagi tubuh, tanaman obat atau apotik hidup juga bisa menjadi tambahan penghasilan bagi masyarakat (T. Setiawati, Annisa, 2019). Hal ini dapat menjadi peluang baru untuk urban farming, maupun berternak sebagai peluang usaha karena dapat menjangkau pasar yang lebih luas.

Berdasarkan latar belakang dan permasalahan di atas, tim pengusul tertarik untuk ikut berpartisipasi menjaga ketahanan pangan Indonesia dengan meningkatkan kesadaran masyarakat akan pentingnya kemandirian pangan dengan membuka pengetahuan masyarakat mengenai peluang usaha dari pemanfaatan sumber daya yang ada di lingkungan sekitar Kelurahan Gunung Tandala, Kecamatan Kawalu, Kota Tasikmalaya. Tim pengusul memiliki program pengabdian kepada masyarakat dengan memberikan pelatihan mengenai pengelolaan dan pengolahan sumber daya yang ada di lingkungan sekitar sebagai alternatif kemandirian pangan, salah satunya adalah urban farming atau berternak.

Mitra di dalam program ini adalah masyarakat terdampak Covid-19 yang menjadi korban PHK atau dirumahkan di industri bordir yang berada di Kelurahan Gunung Tandala, Kecamatan Kawalu, Kota Tasikmalaya. Di tengah kondisi krisis akibat pandemik, kehilangan pekerjaan menjadi tantangan berat yang harus dihadapi oleh mereka untuk dapat bertahan hidup. Keterbatasan pengetahuan masyarakat mengenai pengelolaan dan pengolahan sumber daya untuk menjadi peluang usaha menjadi fokus dari program kami. Kami mengedukasi masyarakat untuk meningkatkan kesadaran mereka terhadap pengelolaan sumber daya yang dapat dilakukan dengan mudah dengan berbagai teknik, seperti urban farming maupun beternak sederhana yang dapat dilakukan dengan cara mudah. Contohnya adalah Kebun Kumara dan Nanem Taneman yang semakin sukses dengan memasarkan berbagai produk urban farming di internet, sejak awal mereka konsisten dalam memberikan edukasi mengenai urban farming dan 
menjual berbagai kebutuhan urban farming. Banyak pula yang menjual hasil produk taninya secara langsung (Fournier, 2018). Contoh dari bidang peternakan, masyarakat dapat mencoba berbagai alternatif, seperti beternak ayam, ikan, kambing, dan lainnya. Bahkan saat ini telah hadir sebuah platform online yang memfasilitasi masyarakat yang ingin berternak namun tidak memiliki cukup lahan untuk dapat berternak, yaitu aplikasi Angon. Salah satu contoh peternakan yang sekarang mulai digalakan adalah dengan adanya Lele Ember yang menjadi kegiatan budidaya/beternak sederhana dan memiliki nilai jual yang cukup tinggi. Generasi milenial seperti inilah yang membuat urban farming dan beternak terlihat menjadi kegiatan yang menyenangkan sehingga semakin membuka kesadaran masyarakat. Berbagai inovasi seperti itulah yang menjadi tujuan program PbM-KP ini untuk dapat mengedukasi masyarakat, khususnya korban PHK dan melihat berbagai peluang usaha dari sumber daya alam. Selain itu, dapat menjadi penghasilan tambahan untuk bertahan hidup dan menjaga kemandirian pangan di tengah situasi ini dan dimasa depan.

\section{Metode Ilmiah}

Program Pengabdian Bagi Masyarakat Skema Ketahanan Pangan (PbM-KP) merupakan metode pendekatan yang ditawarkan oleh tim pengusul dalam membantu mengatasi permasalahan ketahanan pangan, melalui kesadaran masyarakat dalam membangun kemandirian pangan dan menciptakan peluang usaha untuk bertahan hidup bagi masyarakat di Kelurahan Gunung Tandala, Kecamatan Kawalu, Kota Tasikmalaya korban PHK industri bordir. Metode yang digunakan dalam kegiatan pengabdian ini adalah melalui pelatihan dan pendampingan dengan tujuan agar mitra betul-betul memahami cara identifikasi sumberdaya berupa raw material serta mampu memanfaatkannya sebagai peluang usaha dengan meningkatkan kreativitasnya. Selain itu, melalui program $\mathrm{PbM}-\mathrm{KP}$ ini tim pengusul juga akan meminta bantuan dari pakaratau praktisi urban farming dan peternak yang telah berjalan.

Sebelum pelaksanaan program ini sehingga dapat berjalan lancar dan maksimal, maka perlu dilakukan persiapan dan perencanaan secara tepat yang diantaranya:

1. Melakukan pengamatan lapangan dan menganalisis potensi sumber daya alternatif yang relevan dengan program urban farming dan tingkat kesiapan mitra agar kegiatan dapat terlaksana dengan baik.

2. Mengidentifikasi kebutuhan pelaksanaan kegiatan simple urban farming.

3. Menyusun waktu pelaksanaan kegiatan.

4. Mempersiapkan alat dan bahan yang digunakan untuk memberikan pelatihan.

Metode Pelaksanaan yang dilakukan dalam kegiatan pengabdian kepada masyarakat ini adalah:

1. Mitra diberikan penjelasan mengenai ketahanan pangan dan kemandirian pangan dengan cara urban farming dan atau berternak.

2. Mitra diberikan pemahaman mengenai cara identifikasi sumber daya bernilai jual.

3. Mitra diberikan pelatihan untuk dapat menjalankan beberapa teknik, contohnya urban farming maupun peternakan.

4. Mitra diberikan pendampingan dengan berbagai contoh inovasi usaha di bidang pengelolaan dan pengolahan sumber daya bernilai jual. 
Selanjutnya, melakukan monitoring kepada mitra secara rutin melihat perkembangan hasil pelaksanaan kegiatan yang sudah dilakukan oleh mitra. Dalam kegiatan monitoring ini, tim pengusul juga memberikan arahan dan solusi apabila terdapat mitra yang memiliki kendala dalam menjalankan simple urban farming.

\section{Hasil dan Pembahasan}

Tim pelaksana PbM-KP melibatkan mahasiswa Prodi Manajemen untuk melakukan koordinasi kepada kedua mitra, yaitu Bapak Angge dan Bapak Dedi. Bapak Angge merupakan salah satu pengusaha Bordir yang berlokasi di Perumahan Pondok Tandala dan terpaksa gulung tikar karena adanya pandemi Covid-19, sedangkan Bapak Dedi merupakan salah satu karyawan pabrik Bordir yang berlokasi di Bumi Selaras Kawalu dan terkena PHK semenjak adanya pandemi Covid19 yang mengharuskan perusahaan mereka memangkas jumlah karyawannya. Pada pertemuan ini, tim dibantu oleh mahasiswa berusaha mewawancarai dan menggali informasi dari mitra terkait situasi sulit yang dialami oleh mitra, serta berdiskusi mengenai peluang usaha yang dapat diimplementasi saat ini oleh kedua mitra.

Tim pelaksana bersama kedua mitra melakukan pendataan warga setempat yang mengalami situasi dan berstatus sama dengan mitra. Hasil pendataan diperoleh sebanyak 14 warga masyarakat yang mengalami hal serupa dengan mitra. Namun, pada kenyataannya lebih dari 20 orang mitra merupakan mantan karyawan bordir berpartisipasi secara langsung.

Selain itu, tim melakukan pendataan peralatan dan perlengkapan pelaksanaan program $\mathrm{PbM}-\mathrm{KP}$ yang dilakukan secara bersama dengan mitra. Mitra diberikan pilihan alternatif jenis kegiatan, yaitu diantaranya adalah pada bidang pertanian (simple urban farming) atau peternakan (budidaya ikan lele dalam ember). Kedua alterrnatif ini sengaja diberikan untuk menyesuaikan dengan kemampuan pengelolaan dan minat dari setiap mitra untuk menjaga stabilitas kemandirian pangan mereka.

Pada saat pelaksanaan kegiatan, pembuatan prototype fasilitas program dilakukan dengan menyewa tenaga kerja ahli, sehingga menghasilkan contoh alat peraga yang baik. Dengan adanya contoh, masyarakat mitra dapat melihat bagaimana kegiatan PbM-KP ini akan berjalan. Tim pelaksana kegiatan bersama mitra utama dan dibantu oleh asisten teknis, yaitu mahasiswa melaksanakan kegiatan dengan mengundang warga masyarakat menjadi mitra kegiatan untuk secara bersama mengikuti proses pembuatan sarana dan prasarana kegiatan PbM-KP ini. Respon masyarakat sangat baik ketika proses pelaksanaan kegiatan ini berlangsung. Sebanyak 13 warga memilih untuk melakukan simple urban farming, sisanya lebih memilih budidaya ikan lele dalam ember. Proses pendistribusian sarana dan prasarana kegiatan ini dilakukan hingga larut malam.
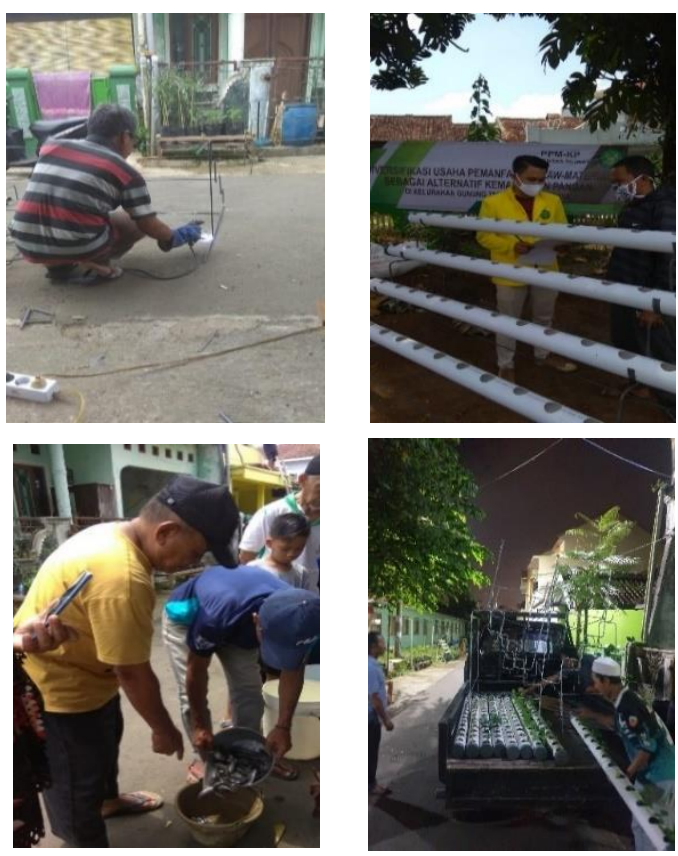

Gambar 1. Pelaksanaan Kegiatan 
Pelaksanaan kegiatan PbM-KP ini mampu memberikan kontribusi kongkrit untuk warga masyarakat, khususnya kepada mantan pekerja industri bordir. Implementasi kegiatan secara umum tidak mengalami kendala yang berarti. Sebagian besar masyarakat mitra merasa senang dan berterimakasih kepada program kegiatan PbM-KP yang telah dilaksanakan. Kegiatan ini bermanfaat bagi masyarakat, serta mampu menjaga kestabilan ketahanan pangan mandiri dari masyarakat mitra. Namun, ada beberapa warga yang mengalami kendala, yaitu adanya beberapa tanaman sayuran yang layu akibat kurang terawat dengan baik. Tim pelaksana memberikan arahan kepada masyarakat mitra supaya lebih intens dalam proses perawatan tanaman sayuran. Sementara itu, masyarakat mitra yang memilih jenis kegiatan budidaya lele dalam ember tidak mengalami hambatan apapun. Selanjutnya, tim pelaksana dalam kegiatan monitoring lapangan memberikan beberapa tips mengenai peluang bisnis yang dapat dimanfaatkan oleh masyarakat mitra terkait dengan jenis kegiatan simple urban farming dan budidaya lele dalam ember. Selain itu, tim pelaksana juga memberikan beberapa pengetahuan dasar untuk memasarkan produk secara online dengan memberikan wawasan mengenai pemasaran dan penjualan melalui saluran online yang dapat membantu meningkatkan penjualan produk (Wahyuni et al., 2020). Hal tersebut menambah motivasi mereka untuk mengelola dan mengembangkan kegiatan serupa di masa yang akan datang.

\section{Kesimpulan dan Saran}

Antusias mitra dan warga yang berstatus sebagai korban PHK industri bordir cukup tinggi karena mereka diberikan kemudahan dan solusi dalam menjaga ketahanan atau kemandirian pangannya melalui program PbM-KP. Hal ini, terlihat dari jumlah peserta yang melebihi hasil pendataan awal untuk kegiatan ini.

Alternatif pilihan program yang diberikan oleh tim pelaksana juga menjadi faktor utama supaya kegiatan $\mathrm{PbM}-\mathrm{KP}$ ini dapat diimplementasikan secara efektif. Sebanyak 13 mitra memilih untuk melakukan simple urban farming, sisanya lebih memilih budidaya ikan lele dalam ember.

Masyarakat mitra menjadi lebih terliterasi mengenai cara untuk menjaga stabilitas kemandirian pangan mereka. Selain itu, masyarakat mitra juga menjadi lebih termotivasi untuk mengembangkan kegiatan, baik berupa simple urban farming dan budidaya lele dalam ember. Setelah, tim memberikan gambaran peluang pasar potensial dari keberhasilan kegiatan ini karena dapat menjadi alternatif sumber pendapatan pengganti setelah mereka diberhentikan dari pekerjaanya.

\section{DAFTAR PUSTAKA}

Burgui, D. (2021). CORONAVIRUS : HOW ACTION AGAINST HUNGER IS. 2-7.

Fournier, A. J. (2018). Direct-selling farming and urban externalities: What impact on product quality and market size? Regional Science and Urban Economics, 70, 97-111. https://doi.org/10.1016/j.regsciurbec o.2018.03.001

Kompasiana. (2020). Pesona Bordir Khas Tasikmalaya yang Mendunia Halaman all - Kompasiana.com. https://www.cnbcindonesia.com/ne ws/20200508200443-4-

157257/soal-phk-pengusaha-punyadata-mengejutkan-ada-7-juta-orang

Kullu, P., Majeedullah, S., Pranay, P. V. S., \& Yakub, B. (2020). Smart urban farming (entrepreneurship through Epics). Procedia Computer Science, 
172(2019),

$452-459$. https://doi.org/10.1016/j.procs.2020. 05.098

(OMS), W. H. O. (2020). COVID-19 Weekly Epidemiological Update. November, 1;4.

Rosales, G., \& Mercado, W. (2020). Effect of changes in food price on the quinoa consumption and rural food security in Peru. Scientia Agropecuaria, 11(1), 83-93. https://doi.org/10.17268/sci.agropec u. 2020.01 .10

Siche, R. (2020). What is the impact of COVID-19 disease on agriculture? Scientia Agropecuaria, 11(1), 3-9. https://doi.org/10.17268/sci.agropec u.2020.01.00

T. Setiawati, Annisa, N. M. (2019). Peningkatan Pemahaman Masyarakat Desa Cinanjung Kecamatan Jatinangor Kabupaten Sumedang terhadap Pemanfaatan Tanaman Krisan sebagai Bahan Obat Herbal dan Pangan Sehat. 8(1), 1624.

Wahyuni, S., B, M., Lubis, A., \& Batubara, S. (2020). Penjualan Online Ikan Asin sebagai salah satu Usaha Meningkatkan Pendapatan Masyarakat Nelayan Bagan Deli. ETHOS (Jurnal Penelitian Dan Pengabdian), $\quad 8(1), \quad 5214$. https://doi.org/10.29313/ethos.v8i1. 5214

Wardoyo, S. (2020). Soal PHK Pengusaha Punya Data Mengejutkan, Ada 7 Juta Orang. CNBC Indonesia. https://www.cnbcindonesia.com/ne ws/20200508200443-4- 157257/soal-phk-pengusaha-punyadata-mengejutkan-ada-7-juta-orang. 